\title{
Craniometric Characteristics and Cranial Indices of Polish Heath Sheep Rams - Extended Data
}

\author{
Características Craneométricas e Índices Craneales \\ de Ovejas Heath Polacas - Datos Ampliados
}

Piotr Baranowski

BARANOWSKI, P. Craniometric characteristics and cranial indices of Polish Heath Sheep rams - extended data. Int. J. Morphol. 35(1):133-140, 2017.

SUMMARY: The study was conducted on the mouflon-derived horned sheep of the preserved Polish Heath Sheep breed. In this study, basic skull measurements of 24 skulls of the rams of different age: 1 day, 90 days, 210 days, 270 days, 3 and 6 years, were analyzed. The weight of each skull was determined, as well as 43 craniometric characteristics were measured, and cranial cavity volume and viscerocranial and neurocranial indices were calculated. From birth to the age of 6 years, the greatest length of the skull, the condylobasal length and the length of the cheek-tooth row increased two-fold. To day 210 of age, the bony housing for eyeball and its organs grew intensively. To day 270 of age, the largest increase was characteristic of the elements of the angular length of the neurocranium and its breadth. The structural elements characterizing both the breadth and the length of the viscerocranium developed to the age of 6 years. A significant $(\mathrm{P} \leq 0.05)$, decreasing with age, value of the cephalic index was observed, being mostly affected by development of the squamous part of the frontal bone with its orbital part and the orbital margin.

KEY WORDS: Skull; Neurocranium and viscerocranium measurements; Polish Heath Sheep; Endangered breeds.

\section{INTRODUCTION}

In the world's population of domestic species, there are such animals which, due to the occurrence of negative phenomena related to development of intensive animal husbandry, e.g. high performance or spread of bio techniques - artificial insemination, embryo transfer, introduction of transgenic animals to animal breeding, have been marginalised because of law performance (Scherf, 2000; Barker, 2001). In Poland, one of these animal populations is the heath sheep. Historically, the heath sheep is derived from primitive Scandinavian sheep (Ryder, 1981; Tapio et al., 2005; Ekman, 2006) which spread over the Baltic Sea and the North Sea coasts during the territorial expansion of the Vikings. The name was formed under the influence of grazing of this type of sheep on poor pastures - heaths. Among these sheep, Polish Heath Sheep has a special place. It was believed that it is derived from the "turbary" sheep. However, the results of morphological studies (Czaja, 1937) and comparative descriptions (Szczepkowski 1951; Baranowski et al., 2006) indicate that it belongs to a group of Northern short tailed sheep (Ovis brachyura borealis) derived from the European mouflon (Ovis musimon). Sheep of this breed are characterised by specific performance parameters, i.e. among others - seasonality of sexual activity and high fecundity (Kiec, 2000; Niznikowski et al., 2002). An interesting craniometric characteristic of the anatomic conformation of males of this sheep breed is huge horns, very similar to those of the mouflon (Lincoln, 1998; Santiago-Moreno et al., 2005; Baranowski et al.).

Sheep are one of the most numerous forms domesticated farm animals making up a large family of bovids (Bovidae), subfamily caprids (Caprinae). The systematics of this subfamily is complicated and is based on many criteria, including those for classification and explanation of phylogenetic relationships between different representatives of caprids, also within the genus Ovis. These criteria are, among others, horns with their horn-cores and horn sheath shape (Schramm, 1967; Flannery, 1969; LasotaMoskalewska et al., 1991), course of cranial sutures (LaprusMadej, 2000), or details of the structure of the petrous part of the temporal bone (Mallet \& Guadelli, 2013). Among wild sheep, the greatest number of forms is found in Central Asia 
and Siberia but the heath sheep examined are derived from the form Ovis musimon $(2 \mathrm{n}=54)$, which means that they are constitutively smaller animals (Kiec') than the Asiatic forms of wild sheep (Kapitanova et al., 2004). Therefore, the search for analogous anatomic characteristic being used for comparing the breeds in the heath sheep type is an important research problem. Since no craniometric studies on the European preserved local heath sheep breed have been conducted so far, it has been undertaken in this study to examine how the skull changes, especially as huge horns are formed on its neurocranium throughout the ram life (Binerowska \& Baranowski, 2010). Skulls of the rams from birth to full somatic maturity were analysed and the findings obtained will contribute to increase knowledge about the anatomy of this part of skeleton and offer data for comparative studies. The present work is a continuation, supplement and an enlargement of earlier research (Baranowski \& Furkioti, 2007).

\section{MATERIAL AND METHOD}

The skulls of twenty-four Polish Heath rams of different age, i.e. 1 day $(n=3), 90$ days $(n=4), 210$ days $(n=$ 4), 270 days $(n=4), 3$ years $(n=5)$ and 6 years $(n=4)$, were measured. They were obtained from animals of pure-bred commercial flock mated with pedigree rams from preservation breeding. The heads of animals were selected from the abattoirslaughtered material based on apparent good health condition and no skeletal deformities. After slaughter, the heads were severed at the atlanto-occipital joint and subsequently processed by hot water maceration technique shortly after the heads were cleaned by removing the eyes and separating most of the skin and attaching muscles. The skulls were cleaned by removing soft tissues, followed by their maceration at about $100 \mathrm{o} C$ for 60 minutes. In the next stage, the skulls were bathed in a $30 \%$ hydrogen peroxide solution (Perhydrol®) to make cranial sutures and syndesmoses visible after cleaning of soft tissues. Subsequently, they were measured. The weight of skull (in g) was determined with an analytical balance, while craniometric measurements were taken with a slide calliper exact to $0.1 \mathrm{~mm}$ and a compass with scale. Measurement of the horn-core basal circumference was made with a measuring-tape.

The measuring technique was adopted after von den Driesch (1976). The following measurements were taken using the definitions of measuring points located on the cranium:

\section{Cranium measurements on the dorsal side:}

(1) Length of the cranium (profile length) from the most aboral point on the vertex of the cranium in the median plane to the median point of the line joining the most oral points of the praemaxillae A-P (Akrokranion - Prosthion).

(8) Length of the cranium (median frontal length) from the most aboral point on the vertex of the cranium in the median plane to the median point of the naso-frontal suture A$\mathrm{N}$ (Akrokranion - Nasion).

(9) Length of the cranium from the most aboral point on the vertex of the cranium in the median plane to the median point of the parieto-frontal suture A-Br (Akrokranion Bregma).

(9a) Length of the cranium (cranial height) B-Br (Basion Bregma) - invisible.

(10) Length of the frontal bone in the sagittal plane (frontal length) from the median point of the parieto-frontal suture to the median point of the naso-frontal suture $\mathrm{Br}-\mathrm{N}$ (Bregma - Nasion).

(11) Length of the cranium (upper neurocranium length) from the most aboral point on the vertex of the cranium in the median plane to the median point of the line joining the aboral borders of the supraorbital foramina A-Sp (Akrokranion Supraorbitale).

(12) Length of the facial part of the cranium (facial length) from the median point of the line joining the aboral borders of the supraorbital foramina to the median point of the line joining the most oral points of the praemaxillae Sp-P (Supraorbitale - Prosthion).

(13) Length of the cranium from the most aboral point on the vertex of the cranium in the median plane to the (dorso) aboral point of the foramen infraorbitale A-If (Akrokranion - Infraorbitale).

(15) Length of the nasal bone (greatest length of the nasals) from the median point of the naso-frontal suture to the median point of the line joining the most oral points of the nasals $\mathrm{N}-\mathrm{Rh}$ (Nasion - Rhinion).

(16) Lateral length of the facial part of the cranium (short lateral facial length) from the naso-medial indentation of the orbit that corresponds with the inner angle of the eye in the living animal to the median point of the line joining the most oral points of the praemaxillae Ent-P (Entorbitale - Prosthion).

(33) Greatest breadth of the neurocranium (greatest length of brain-case) between the most lateral point of the braincase on the left and the most lateral point of the brain-case on the right Eu-Eu (Euryon - Euryon). 
(34) Greatest breadth across the orbits (greatest frontal breadth) between the most lateral point of the frontal bone on the occipital side of the orbit on the left and the most lateral point of the frontal bone on the occipital side of the orbit on the right Ect-Ect (Ectorbitale Ectorbitale).

(35) Least breadth between the orbits, i.e. between the nasomedial indentation of the orbit that corresponds with the inner angle of the eye in the living animal on the left and the nasomedial indentation of the orbit that corresponds with the inner angle of the eye in the living animal on the right Ent-Ent (Entorbitale - Entorbitale).

(36) Breadth of the facial part of the cranium (facial breadth), i.e. distance across the facial tuberosities $\mathrm{Sm}-\mathrm{Sm}$ (Supramorale - Supramorale).

(37) Greatest breadth across the nasals.

(38) Greatest breadth across the praemaxillae.

\section{Measurements on the left-hand side:}

(6) Angular height of the neurocranium (neurocranium length) from the median point of the naso-frontal suture to the orobasal border of the foramen magnum in the median plane N-B (Nasion - Basion).

(7) Angular height of the viscerocranium (viscerocranium length) from the median point of the naso-frontal suture to the median point of the line joining the most oral points of the praemaxillae N-P (Nasion - Prosthion).

(14) Greatest length of the lacrimal bone from the most lateral point of the lacrimal to the most oral point of the lacrimo-maxillary suture.

(17) Length from the aboral border of one occipital condyle to the (dorso) aboral point of the foramen infraorbitale $(\mathrm{Cd}$ - If).

(20) Length of the praemaxilla (lateral length of the praemaxilla) from the most aboral point of the praemaxilla on the facial surface to the median point of the line joining the most oral points of the praemaxillae $\mathrm{Ni}-\mathrm{P}$ (Nasointermaxillare - Prosthion).

(24) Greatest inner length of the orbit from the most lateral point of the frontal bone on the occipital side of the orbit to the naso-medial indentation of the orbit that corresponds with the inner angle of the eye in the living animal Ect-Ent (Ectorbitale - Entrobitale).
(25) Greatest inner height of the orbit, measured in the same way as the above measurement.

(25a) Orbit area: using the formula $22 / 7 \mathrm{ab}$, where a and $\mathrm{b}$ are the halves of orbital length (24) and width (25), respectively.

\section{Measurements on the basal side:}

(2) Condylobasal length of the cranium from the aboral border of occipital condyles $(\mathrm{Cd})$ to the median point of the line joining the most oral points of the praemaxillae (Prosthion).

(3) Length of the cranium base (basal length) from the orobasal border of the foramen magnum in the median plane to the median point of the line joining the most oral points of the praemaxillae B-P (Basion - Prosthion).

(4) Length of the cranium from the orobasal border of the foramen magnum in the median plane to the median point of the line joining the oral points of the alveoli of the foremost cheek teeth (short skull length) B-Pm (Basion - Praemolare).

(5) Length of the anterior toothless part of the upper tooth row from the median point of the line joining the oral points of the alveoli of the foremost cheek teeth to the median point of the line joining the most oral points of the praemaxillae Pm-P (Praemolare - Prosthion).

(18) Length of the maxilla (dental length) from the median point of the line joining the aboral points of the alveoli of the hindmost cheek teeth to the median point of the line joining the most oral points of the praemaxillae Pd-P (Postdentale Prosthion).

(19) Length of the palate (oral palatal length) from the median point of the palatine-maxillary suture to the median point of the line joining the most oral points of the praemaxillae Po-P (Palatinoorale - Prosthion).

(21) Length of the praemolar and molar tooth row (length of the cheek-tooth row).

(22) Length of the moral tooth row.

(23) Length of the praemolar tooth row.

(39) Greatest palatal breadth.

\section{Measurements on the nuchal side:}

(26) Greatest breadth of the occipital bone (greatest mastoid breadth) from the most lateral point of the masteoid region 
on the left to the most lateral point of the masteoid region on the right Ot-Ot (Otion - Otion).

(27) Greatest breadth of the occipital condyles.

(28) Greatest breadth at the bases of the paraoccipital processes.

(29) Greatest breadth of the foramen magnum.

(30) Height of the foramen magnum from the orobasal border of the foramen magnum in the median plane to the nuchodorsal border of the foramen magnum in the median plane $\mathrm{B}-\mathrm{O}$ (Basion - Opisthion).

(30a) Foramen magnum area: using the formula $\approx$ wh, where $\mathrm{w}=$ breadth (29) and $\mathrm{h}=$ height of the foramen magnum (30).

\section{Measurements of ram horn-cores:}

(32) Greatest breadth between the lateral borders of the horncore bases.

(40) Horn-core basal circumference.
(41) Greatest (oro-aboral) diameter of the horn-core base.

(42) Least (latero-medial) diameter of the horn-core base.

(43) The horn sheath length.

\section{Selected cranial indices were also calculated:}

1) Ect-Ect $\mathrm{x}$ 100/A-P; 2) Ect-Ect $\mathrm{x}$ 100/A-N; 3) Ect-Ect $\mathrm{x}$ 100/N-P; 4) Ent-Ent x 100/Br-N;

5) Eu-Eu x 100/A-N; 6) Eu-Eu x 100/A-P; 7) Eu-Eu x 100/NB; 8) Eu-Eu x 100/B-P;

9) Eu-Eu x 100/A-Po; 10) N-B x 100/B-P; 11) N-P x 100/BP; 12) Sm-Sm x 100/N-P;

13) Greatest palatal breadth $\mathrm{x}$ 100/B-P; 14) Pm-Pd x 100/PdP; 15) P1-M3/B-P;

16) Orbital index; 17) Nasal index: greatest breadth across the nasals x 100/N-Rh;

18) Foramen magnum index: greatest breadth of the f. m. $x$ 100/B-O;

19) Cephalic index: Eu-Eu x A-N x B-Br.

Table I. Weight of rams skull.

\begin{tabular}{lcccccc}
\hline \multirow{2}{*}{ Trait } & 1 day $(\mathrm{n}=3)$ & 90 days $(\mathrm{n}=4)$ & 210 days $(\mathrm{n}=4)$ & 270 days $(\mathrm{n}=4)$ & 3 years $(\mathrm{n}=5)$ & 6 years $(\mathrm{n}=4)$ \\
\hline $\mathrm{x}$ & 27.80 & 72.75 & 364.71 & 437.61 & 1277.00 & 2073.00 \\
$\mathrm{sd}$ & 1.41 & 7.30 & 50.94 & 42.19 & 216.38 & 302.75 \\
min. & 26.60 & 64.60 & 288.35 & 396.95 & 1000.00 & 1720.00 \\
max. & 29.40 & 79.50 & 392.90 & 495.10 & 1550.00 & 2460.00 \\
V\% & 5.19 & 10.04 & 13.97 & 9.64 & 16.94 & 14.59 \\
\hline
\end{tabular}

Table II. Measurements on the dorsal side.

\begin{tabular}{|c|c|c|c|c|c|c|c|c|c|c|c|c|}
\hline \multirow[t]{3}{*}{ Trait } & \multicolumn{12}{|c|}{ Age of rams } \\
\hline & \multicolumn{2}{|c|}{1 day $(n=3)$} & \multicolumn{2}{|c|}{90 days $(n=4)$} & \multicolumn{2}{|c|}{210 days $(n=4)$} & \multicolumn{2}{|c|}{270 days $(n=4)$} & \multicolumn{2}{|c|}{3 years $(n=5)$} & \multicolumn{2}{|c|}{6 years $(n=4)$} \\
\hline & $\mathrm{x}$ & SD & $\mathrm{x}$ & SD & $\mathrm{x}$ & SD & $\mathrm{x}$ & SD & $\mathrm{x}$ & SD & $\mathrm{x}$ & SD \\
\hline 1 & $101.30 \mathrm{a}^{\mathrm{bcA}}$ & 3.00 & $133.50 \mathrm{~d}$ & 3.24 & $181.65^{\mathrm{a}}$ & 4.42 & $181.55 b$ & 7.45 & $199.90^{\mathrm{c}}$ & 9.35 & $231.00 \mathrm{~A}^{\mathrm{d}}$ & 18.41 \\
\hline 8 & $61.73 \mathrm{a}^{\mathrm{DA}}$ & 3.93 & 84.48 & 2.87 & $98.48 \mathrm{a}$ & 2.14 & 96.60 & 4.24 & $120.26^{\mathrm{D}}$ & 2.72 & $126.74^{\mathrm{A}}$ & 9.31 \\
\hline 9 & $15.63 \mathrm{aA}^{\mathrm{b}}$ & 3.32 & 27.98 & 1.77 & $30.60 \mathrm{a}$ & 3.31 & 28.60 & 3.74 & $91.05^{\mathrm{A}}$ & 4.25 & $92.87 \mathrm{~b}$ & 12.88 \\
\hline $9 a$ & $35.45 \mathrm{a}^{\mathrm{bA}}$ & 4.79 & 54.86 & 1.08 & $58.25 \mathrm{a}$ & 3.16 & 54.55 & 4.46 & $101.81^{\mathrm{b}}$ & 2.59 & $108.29^{\mathrm{A}}$ & 1.22 \\
\hline 10 & $47.17 \mathrm{aA}^{\mathrm{BC}}$ & 2.12 & 65.33 & 2.00 & $74.15 \mathrm{a}$ & 1.71 & $76.80 \mathrm{~A}$ & 1.07 & 78.05 в & 2.25 & $77.95^{\mathrm{C}}$ & 1.81 \\
\hline 11 & $45.37 \mathrm{aA}^{\mathrm{b}}$ & 2.57 & 61.95 & 1.90 & $69.80 \mathrm{a}$ & 6.68 & 64.95 & 4.79 & $100.67 \mathrm{~A}$ & 3.04 & $106.71 \mathrm{~b}$ & 12.24 \\
\hline 12 & $55.20 \mathrm{a}^{\mathrm{bA}}$ & 2.80 & 75.33 & 2.03 & $107.23^{\mathrm{a}}$ & 3.13 & 106.48 & 3.01 & $133.87^{\mathrm{b}}$ & 4.84 & $159.45^{\mathrm{A}}$ & 17.95 \\
\hline 13 & $75.40 \mathrm{a}^{\mathrm{bA}}$ & 2.12 & 97.03 & 1.11 & $128.70^{\mathrm{a}}$ & 2.92 & 126.85 & 3.86 & $136.98^{\mathrm{b}}$ & 4.65 & $145.00^{\mathrm{A}}$ & 6.16 \\
\hline 15 & $27.31^{\mathrm{AbA}}$ & 0.81 & 36.40 & 0.69 & $62.08 \mathrm{a}$ & 6.15 & 61.05 & 1.48 & $72.99 \mathrm{~b}$ & 5.77 & $86.42^{\mathrm{A}}$ & 11.96 \\
\hline 16 & $51.93 \mathrm{a}^{\mathrm{bA}}$ & 1.44 & 70.74 & 4.89 & $108.50^{\mathrm{a}}$ & 7.53 & 103.10 & 3.43 & $122.98^{\mathrm{b}}$ & 1.12 & $141.40^{\mathrm{A}}$ & 14.64 \\
\hline 33 & $42.47 \mathrm{aA}^{\mathrm{B}}$ & 2.99 & 53.48 & 1.75 & 56.83 & 4.87 & $64.33 \mathrm{a}$ & 2.01 & $92.26^{\mathrm{A}}$ & 1.29 & $93.82^{\mathrm{B}}$ & 5.21 \\
\hline 34 & $61.43 \mathrm{a}^{\mathrm{bcA}}$ & 3.06 & 81.54 & 1.30 & $100.85^{\mathrm{a}}$ & 5.69 & $97.58 \mathrm{~b}$ & 5.21 & $109.20^{\mathrm{c}}$ & 2.57 & $119.01^{\mathrm{A}}$ & 7.92 \\
\hline 35 & $41.13 \mathrm{a}^{\mathrm{bA}}$ & 2.31 & 55.85 & 2.09 & $72.81 \mathrm{a}$ & 7.83 & 70.88 & 2.97 & $80.99 b$ & 2.59 & $85.73^{\mathrm{A}}$ & 6.53 \\
\hline 36 & $35.21 \mathrm{a}^{\mathrm{bA}}$ & 0.47 & 46.43 & 0.78 & $58.75 \mathrm{a}$ & 5.64 & 58.85 & 3.30 & $71.09 \mathrm{~b}$ & 1.05 & $73.28^{\mathrm{A}}$ & 5.87 \\
\hline 37 & $17.31 \mathrm{Aa}^{\mathrm{B}}$ & 0.40 & 20.80 & 0.67 & 24.48 & 3.40 & $31.55 \mathrm{~A}$ & 5.70 & $30.02^{\mathrm{a}}$ & 1.24 & $33.14^{\mathrm{B}}$ & 2.35 \\
\hline 38 & $21.49 \mathrm{a}$ & 0.79 & 24.71 & 0.34 & 33.20 & 2.77 & $33.88 \mathrm{a}$ & 2.37 & 38.05 & 1.20 & 40.18 & 3.90 \\
\hline
\end{tabular}

Explanation: means bearing the same large letter within each line differ significantly at $\mathrm{P}<0.01$; means bearing the same small letter within each line differ significantly at $\mathrm{P}<0.05$. 
The measurement results obtained were analysed statistically using Statistica v.10.0 PL computer software. In the absence of normal distribution, differences between the groups of rams were evaluated with the Kruskal-Wallis non-parametric test.

\section{RESULTS}

The average weight of the skulls of Polish Heath Sheep rams being used in craniometric analysis is presented in Table I. The greatest differences in weight were characteristic of the skulls of animals at the age of three years $(\mathrm{V}=16.94 \%)$. The weight of other specimens in the age groups were similar, and the values of coefficients of variation ranged from $\mathrm{V} \%=5.19$ to $\mathrm{V} \%=14.59$. The highest rate of increase in the weight of ram skull occurred between day 90 and day 210 of age. During this period, the skull weight increased approximately $2.43 \mathrm{~g} /$ day. From birth to day 90 of age, an increase in the skull weight amounted to $0.50 \mathrm{~g} / \mathrm{day}$, whereas between day 210 and day $270-1.21 \mathrm{~g} /$ day. The weight of 3- and 6-year-old skulls was determined together with the horn sheath on their horn cores, which has a significant effect on the obtained results. It should be also noted that some of the horns had their tips corrected as they were directed towards the facial part of the head, posing a threat to the rams' health.

Tables II-VI present the results of craniometric measurements. From birth to 6 years of age, the greatest length of the skull A-P (measurement 1) increased more than twofold, reaching on average $231.00 \mathrm{~mm} \pm 18.41$. During the first 270 days of age,the largest increase was characteristic of the elements of the angular length of the neurocranium: A-N (measurement 8), A-Br (measurement 9), Br-N (measurement 10), and its breadth Eu-Eu (measurement 33). To day 210 of age, the bony housing for eyeball and its organs grew intensively: Ect-Ect (measurement 34) and Ent-Ent (measurement 35). These characteristics further increased in adult animals but at a lower rate. The structural elements characterising both the breadth and the length of the viscerocranium: length of the nasal bone $\mathrm{N}-\mathrm{Rh}$ (measurement 15), breadth of the facial part of the cranium across the facial tuberosities $\mathrm{Sm}-\mathrm{Sm}$ (measurement 36 ), greatest breadth across the nasals (measurement 37 ) and greatest breadth across the premaxillae (measurement 38), developed to the age of full somatic maturity of rams (Table II).

Measurement on the lateral side of the skulls (Table III) showed a significant $(\mathrm{P} \leq 0.05)$ increase in the angular height of the neurocranium N-B (measurement 6) to day 270 of age. On the other hand, it was smaller and not significant statistically in the next periods. To day 270 of age, the angular height of the viscerocranium N-P (measurement 7) and the length of the praemaxilla Ni-P (measurement 20) increased as well. Substantial broadening of the neurocranium and development of the bony housing for eyeball was accompanied to day 270 of age by a significant $(\mathrm{P} \leq 0.05)$ increase in the length of the orbit (measurement 24) and its height (measurement 25), almost doubling the orbit area (measurement 25a). These characteristics further increased in adult animals but not as fast as in the first year of age.

The measurement made on the skull base (Table IV) showed a more than two-fold increase in the condylobasal length and the characteristics of the basal length from birth to the sixth year of age. During this period, the length of the cheek-tooth row (measurement 21), including the length of the premolar tooth row (measurement 23) and the length of the molar tooth row (measurement 22), and the greatest palatal breadth (measurement 39) increased two-fold as well.

Measurements of the craniometric characteristics of the nuchal plate (Table V) showed stabilization of the breadth of the occipital bone even before the first year of age. At full maturity, this area did not increased. Only the paraoccipital processes developed. The foramen magnum area (measurement 30a), as well as its breadth (measurement 29) and height (measurement 30), stabilised rather early, too.

Table III. Measurements on the left-lateral view.

\begin{tabular}{|c|c|c|c|c|c|c|c|c|c|c|c|c|}
\hline \multirow[b]{3}{*}{ Trait } & \multicolumn{12}{|c|}{ Age of rams } \\
\hline & \multicolumn{2}{|c|}{1 day $(n=3)$} & \multicolumn{2}{|c|}{90 days $(n=4)$} & \multicolumn{2}{|c|}{210 days $(n=4)$} & \multicolumn{2}{|c|}{270 days $(n=4)$} & \multicolumn{2}{|c|}{3 years $(n=5)$} & \multicolumn{2}{|c|}{6 years $(n=4)$} \\
\hline & $\mathrm{x}$ & SD & $\mathrm{x}$ & SD & $\mathrm{x}$ & SD & $\mathrm{x}$ & SD & $\mathrm{x}$ & SD & $\mathrm{x}$ & SD \\
\hline 6 & $66.60 \mathrm{a}^{\mathrm{bA}}$ & 2.21 & $86.38 \mathrm{c}$ & 2.82 & 101.53 & 1.37 & $104.40^{\mathrm{a}}$ & 5.92 & $118.20^{b}$ & 1.10 & $121.75 \mathrm{Ac}$ & 7.18 \\
\hline 7 & $46.50 \mathrm{a}^{\mathrm{bA}}$ & 1.24 & $56.70 \mathrm{c}$ & 1.26 & 91.12 & 6.55 & $94.55 \mathrm{a}$ & 6.64 & $116.78^{b}$ & 6.00 & $138.81 \mathrm{Ac}$ & 14.56 \\
\hline 14 & $17.79 \mathrm{a}^{\mathrm{bAB}}$ & 0.52 & $30.23 \mathrm{~d}$ & 0.84 & $39.58^{\mathrm{a}}$ & 1.73 & $39.33 b$ & 2.61 & $40.20 \mathrm{~A}$ & 0.86 & $44.07 \mathrm{~B}^{\mathrm{d}}$ & 4.32 \\
\hline 17 & $73.89 \mathrm{aA}^{\mathrm{B}}$ & 1.47 & 94.31 & 2.71 & 129.60 & 2.97 & 123.72 & 4.31 & 136.60 & 2.61 & 153.85 & 15.69 \\
\hline 20 & $29.40 \mathrm{a}^{\mathrm{bA}}$ & 1.26 & 38.13 & 0.81 & $59.95^{\mathrm{a}}$ & 2.61 & $57.90 \mathrm{~b}$ & 1.60 & 65.57 & 1.73 & $79.18 \mathrm{~A}$ & 10.69 \\
\hline 24 & $25.73 \mathrm{a}^{\mathrm{bAc}}$ & 0.91 & 28.88 & 0.47 & $35.23^{\mathrm{a}}$ & 0.33 & $35.63 \mathrm{~b}$ & 1.94 & $39.59 \mathrm{c}$ & 1.20 & $41.20 \mathrm{~A}$ & 1.84 \\
\hline 25 & $22.37 \mathrm{a}^{\mathrm{bA}}$ & 1.40 & 26.08 & 0.52 & $32.54^{\mathrm{a}}$ & 0.31 & 33.98 & 2.26 & $39.15 b$ & 084 & 39.36A & 1.64 \\
\hline $25 \mathrm{a}$ & $4.53 \mathrm{a}^{\mathrm{bA}}$ & 0.45 & 5.92 & 0.18 & 9.00 & 0.26 & $9.53 \mathrm{a}$ & 1.02 & $12.18 \mathrm{~b}$ & 0.49 & $12.74 \mathrm{~A}$ & 0.89 \\
\hline
\end{tabular}

Explanation: means bearing the same large letter within each line differ significantly at $\mathrm{P}<0.01$; means bearing the same small letter within each line differ significantly at $\mathrm{P}<0.05$. 
The heath sheep are horned animals. As with horned goats and horned cattle, the pneumatised frontal bone (with the frontal sinus) develops a process called a horn core. It forms a bony framework for the proper horn, being an epidermal derivative. In sheep, it starts just behind the orbits. Measurement of this part (measurement 32) showed an increase in the cranium breadth during the whole life or rams, being only significant $(\mathrm{P} \leq 0.05)$ in the first year of age. Measurement at the neck of the cornual process (collum processus cornualis) (measurement 40) showed more than two-fold development of this element as early as the first year of age and in next periods. Nearly $19 \%$ coefficient of variation determined for these characteristics indicates a high variability of this structure intended for future setting of the horn sheath. Other measurements include the skin appendix itself, i.e. the horn sheath length (measurement 43), which reached an average value of $556.25 \mathrm{~mm} \pm 85.57$ (without tips) in six-year-old animals.

Table VII presents the average values of craniometric indices of the rams being analysed. From the first day after birth to the age of 6 years, the volume of the cranial cavity of the ram skulls (index 19) increased more than thirteen-fold. The skulls, as the rams reached maturity, became longer and narrower. The neurocranium was the broadest in the place of orbit setting between day 210 and day 270 of age. As the horn core (being formed just behind the orbits) developed and the horn built up on it, the neurocranium increased its dimensions. This is illustrated by an increase in the values of the cranium index Eu-Eu/A-N (index 5), by more than $14 \%$, and the cranial index Eu-Eu/A-P (index 6), by more than $30 \%$, in three-yearold animals. This process was accompanied by a decrease in the participation of the neurocranium length and an increase in the participation of the viscerocranium length. An expression of this phenomenon is the values of indices (10) and (11). Changes in the proportion of the viscerocranium are showed by the values of indices (12) to (15) and (17).
Ultimately, development of the squamous part of the frontal bone with its orbital part (pars orbitalis) and orbital margin (margo orbitalis), being the components of the dimension Ectorbitale-Ectorbitale, had the greatest effect on a decreasing value of the cranial index 1 , with an increasing length of the viscerocranium.

\section{DISCUSSION}

The skulls of the analysed Polish Heath Sheep are broader and shorter than those of polled Spanish Xisqueta sheep (Parés-Casanova et al., 2010), the skull index and the cranium index of which have lower values $(44.69 \%$ v. 51.58 $\%$ and $48.33 \%$ v. $40.69 \%$, respectively). The values of such indices as the nasal index, basal index and facial index being determined for the Polish Heath Sheep skulls are higher than those calculated for the skulls of Tuj and Morkaraman sheep from the north-eastern Anatolia (Özcan et al., 2010). They are also shorter than the skulls of sheep from Trinidad (Mohamed et al., 2016). The values for palatal dimensions (measurement 18 - P-Pd, measurement 19 - P-Po and measurement 39 - greatest palatal breadth) in the Polish Heath Sheep are higher than those in each of the two sheep breeds from Anatolia. On the other hand, they are inferior to them in the values of such dimensions as, among others, the greatest length of the skull and the condylobasal length. Also the viscerocranium length, the length of the nasal bone and length of the cheek-tooth row, including the length of the praemolar tooth row and that of the molar tooth row, have lower values than those determined on the skulls of the sheep mentioned above but they certainly had an effect on the weight of the viscerocranium (Parés-Casanova, 2014).

The values for the nuchal region dimensions, such as breadth and the height of the foramen magnum, are lower

Table IV. Measurements of basal side (Ventral view).

\begin{tabular}{|c|c|c|c|c|c|c|c|c|c|c|c|c|}
\hline \multirow[b]{3}{*}{ Trait } & \multicolumn{12}{|c|}{ Age of rams } \\
\hline & \multicolumn{2}{|c|}{1 day $(n=3)$} & \multicolumn{2}{|c|}{90 days $(n=4)$} & \multicolumn{2}{|c|}{210 days $(n=4)$} & \multirow{2}{*}{\multicolumn{2}{|c|}{$\begin{array}{l}270 \text { days } \\
\mathrm{x}(\mathrm{n}=4) \mathrm{SD}\end{array}$}} & \multicolumn{2}{|c|}{3 years $(n=5)$} & \multicolumn{2}{|c|}{6 years $(n=4)$} \\
\hline & $\mathrm{x}$ & $\mathrm{SD}$ & $\mathrm{x}$ & $\mathrm{SD}$ & $\mathrm{x}$ & $\mathrm{SD}$ & & & $\mathrm{x}$ & SD & $\mathrm{x}$ & SD \\
\hline 2 & $110.37^{\mathrm{abA}}$ & 2.04 & 138.23 & 2.06 & $188.15 \mathrm{a}$ & 4.67 & 185.63 & 6.4 & $210.75^{b}$ & 1.71 & 233.50 & 19.55 \\
\hline 3 & $94.41^{\mathrm{aAB}}$ & 1.06 & $118.73^{\mathrm{c}}$ & 3.93 & $168.80 \mathrm{a}$ & 4.33 & 160.65 & 6.6 & $194.00 \mathrm{~A}$ & 3.37 & 213.00 & 14.63 \\
\hline 4 & $67.43 \mathrm{a}^{\mathrm{bA}}$ & 0.85 & 90.10 & 5.68 & $121.40 \mathrm{a}$ & 3.65 & 122.73 & 5.2 & $142.33^{\mathrm{b}}$ & 2.70 & 152.68 & 10.51 \\
\hline 5 & $23.32 \mathrm{a}^{\mathrm{bA}}$ & 1.50 & 32.53 & 0.99 & $47.53 \mathrm{a}$ & 2.79 & 46.00 & 3.6 & $53.52 \mathrm{~b}$ & 2.38 & $60.77 \mathrm{~A}$ & 4.19 \\
\hline 18 & $52.32 \mathrm{a}^{\mathrm{bA}}$ & 0.74 & 64.60 & 4.08 & $93.48 \mathrm{a}$ & 6.42 & 89.93 & 4.1 & $107.62^{b}$ & 0.44 & 121.28 & 8.97 \\
\hline 19 & $44.71 \mathrm{a}^{\mathrm{bcA}}$ & 0.69 & 53.48 & 0.53 & $74.08 \mathrm{a}$ & 3.45 & $74.18 \mathrm{~b}$ & 3.8 & $85.99^{c}$ & 0.54 & $96.31 \mathrm{~A}$ & 6.04 \\
\hline 21 & $32.50^{\mathrm{AaB}}$ & 0.71 & 38.43 & 0.56 & $47.65 \mathrm{~A}$ & 2.21 & 44.93 & 1.5 & $67.25^{\mathrm{a}}$ & 0.94 & $69.04 \mathrm{~B}$ & 7.58 \\
\hline 22 & $20.21^{\mathrm{a}}{ }^{\mathrm{DA}}$ & 0.53 & 26.70 & 0.42 & $28.38^{\mathrm{a}}$ & 0.96 & 27.45 & 1.3 & $33.93 \mathrm{~b}$ & 0.54 & $35.01 \mathrm{~A}$ & 2.73 \\
\hline 23 & $13.37 \mathrm{aA}$ & 1.76 & 13.89 & 0.20 & $18.88 \mathrm{a}$ & 1.42 & 17.10 & 1.9 & $36.27^{\mathrm{A}}$ & 1.72 & 30.89 & 4.03 \\
\hline 39 & $37.49^{\mathrm{ABa}}$ & 0.36 & 44.85 & 0.49 & $57.35 \mathrm{~A}$ & 2.31 & 54.75 & 1.4 & $65.96 \mathrm{~B}$ & 1.31 & $66.61^{\mathrm{a}}$ & 5.53 \\
\hline
\end{tabular}

Explanation: means bearing the same large letter within each line differ significantly at $\mathrm{P}<0.01$; means bearing the same small letter within each line differ significantly at $\mathrm{P}<0.05$. 
Table V. Measurements on the nuchal side (Occipital view).

\begin{tabular}{|c|c|c|c|c|c|c|c|c|c|c|c|c|}
\hline \multirow[b]{3}{*}{ Trait } & \multicolumn{12}{|c|}{ Age of rams } \\
\hline & \multicolumn{2}{|c|}{1 day $(n=3)$} & \multicolumn{2}{|c|}{90 days $(n=4)$} & \multicolumn{2}{|c|}{210 days $(n=4)$} & \multicolumn{2}{|c|}{270 days $(n=4)$} & \multicolumn{2}{|c|}{3 years $(n=5)$} & \multicolumn{2}{|c|}{6 years $(n=4)$} \\
\hline & $\mathrm{x}$ & SD & $\mathrm{x}$ & SD & $\mathrm{x}$ & SD & $\mathrm{x}$ & SD & $\mathrm{x}$ & SD & $\mathrm{x}$ & SD \\
\hline 26 & $53.50^{\mathrm{ab}}$ & 0.66 & 65.23 & 0.75 & $87.35 \mathrm{a}$ & 2.72 & 85.95 & 8.51 & 84.42 & 4.09 & $85.04 \mathrm{~b}$ & 5.22 \\
\hline 27 & $29.43 \mathrm{a}^{\mathrm{bA}}$ & 0.65 & $36.08^{\mathrm{c}}$ & 1.42 & $42.18 \mathrm{a}$ & 2.75 & 40.68 & 1.36 & $47.01 \mathrm{~b}$ & 1.85 & $49.30 \mathrm{Ac}$ & 3.21 \\
\hline 28 & $36.07 \mathrm{a}^{\mathrm{bA}}$ & 0.15 & 44.83 & 0.39 & $56.25 \mathrm{a}$ & 1.91 & 54.73 & 3.08 & $70.11 \mathrm{~b}$ & 0.90 & $72.53 \mathrm{~A}$ & 6.98 \\
\hline 29 & 14.31 & 0.67 & 15.69 & 1.28 & 17.80 & 1.35 & 16.68 & 0.95 & 16.59 & 0.72 & 17.37 & 1.91 \\
\hline 30 & 12.50 & 0.52 & 15.59 & 0.89 & 15.53 & 0.99 & 14.60 & 0.42 & 13.42 & 0.62 & 14.30 & 1.33 \\
\hline $30 \mathrm{a}$ & $0.45 \mathrm{a}$ & 0.04 & 0.71 & 0.10 & $0.69 \mathrm{a}$ & 0.05 & 0.60 & 0.04 & 0.55 & 0.03 & 0.62 & 0.09 \\
\hline
\end{tabular}

Explanation: means bearing the same large letter within each line differ significantly at $\mathrm{P}<0.01$; means bearing the same small letter within each line differ significantly at $\mathrm{P}<0.05$.

Table VI. Measurements of ram horns (The frontal part of the skull).

\begin{tabular}{|c|c|c|c|c|c|c|c|c|c|c|c|c|}
\hline \multirow{3}{*}{ Trait } & \multicolumn{12}{|c|}{ Age of rams } \\
\hline & \multicolumn{2}{|c|}{1 day $(n=3)$} & \multicolumn{2}{|c|}{90 days $(n=4)$} & \multicolumn{2}{|c|}{210 days $(n=4)$} & \multicolumn{2}{|c|}{270 days $(n=4)$} & \multicolumn{2}{|c|}{3 years $(n=5)$} & \multicolumn{2}{|c|}{6 years $(n=4)$} \\
\hline & $\mathrm{x}$ & SD & $\mathrm{x}$ & SD & $\mathrm{x}$ & SD & $\mathrm{x}$ & SD & $\mathrm{x}$ & SD & $\mathrm{x}$ & SD \\
\hline 32 & - & - & $63.98^{\mathrm{ab}}$ & 2.19 & 82.73 & 1.76 & 83.60a & 5.04 & 93.68 & 6.08 & $94.74 \mathrm{~b}$ & 6.01 \\
\hline 40 & - & - & $13.33 \mathrm{~A}$ & 0.46 & 37.68 & 4.24 & 38.15 & 7.22 & 40.29 & 1.63 & $43.03^{\mathrm{A}}$ & 2.36 \\
\hline 41 & - & - & $26.70^{\mathrm{ab}}$ & 0.89 & 45.20 & 4.83 & $47.72 \mathrm{a}$ & 9.57 & 53.97 & 1.93 & $57.56 \mathrm{~b}$ & 6.73 \\
\hline 42 & - & - & $67.90 \mathrm{aA}$ & 3.92 & 132.00 & 11.6 & $137.22 \mathrm{a}$ & 29.71 & 171.40 & 12.92 & $197.55^{\mathrm{A}}$ & 12.03 \\
\hline 43 & - & - & $58.25 \mathrm{aA}$ & 5.25 & 238.25 & 39.18 & 217.53 & 74.17 & $484.00 \mathrm{a}$ & 213.05 & $556.25^{\mathrm{A}}$ & 85.57 \\
\hline
\end{tabular}

Explanation: means bearing the same large letter within each line differ significantly at $\mathrm{P}<0.01$; means bearing the same small letter within each line differ significantly at $\mathrm{P}<0.05$.

Table VII. The value of cranial indices of Polish Heath Sheep rams.

\begin{tabular}{|c|c|c|c|c|c|c|c|c|c|c|c|c|}
\hline \multirow{3}{*}{$\begin{array}{l}\text { Cranial } \\
\text { indices }\end{array}$} & \multicolumn{12}{|c|}{ Age of rams } \\
\hline & \multicolumn{2}{|c|}{1 day $(n=3)$} & \multicolumn{2}{|c|}{90 days $(n=4)$} & \multicolumn{2}{|c|}{210 days $(n=4)$} & \multicolumn{2}{|c|}{270 days $(n=4)$} & \multicolumn{2}{|c|}{3 years $(n=5)$} & \multicolumn{2}{|c|}{6 years $(n=4)$} \\
\hline & $\mathrm{x}$ & $\mathrm{sd}$ & $\mathrm{x}$ & $\mathrm{sd}$ & $\mathrm{x}$ & $\mathrm{sd}$ & $\mathrm{x}$ & $\mathrm{sd}$ & $\mathrm{x}$ & $\mathrm{sd}$ & $\mathrm{x}$ & sd \\
\hline 1 & $60.65^{a}$ & 2.52 & $61.10^{\mathrm{cd}}$ & 1.32 & 55.49 & 2.03 & $53.75^{b c}$ & 1.99 & 54.75 & 3.41 & $51.58^{\mathrm{ad}}$ & 1.91 \\
\hline 2 & 99.61 & 3.29 & 96.61 & 3.20 & 102.39 & 4.83 & 101.17 & 4.21 & 90.85 & 3.31 & 93.94 & 0.77 \\
\hline 3 & 132.06 & 3.31 & $143.85^{\mathrm{Aa}}$ & 1.98 & 110.92 & 7.37 & $103.85^{\mathrm{A}}$ & 12.89 & 93.62 & 2.90 & $89.29^{\mathrm{a}}$ & 4.82 \\
\hline 4 & $87.18^{\mathrm{a}}$ & 1.08 & $85.49^{\mathrm{bcB}}$ & 1.02 & $102.45^{\mathrm{b}}$ & 2.89 & $93.90 \mathrm{~d}$ & 10.69 & $103.82^{\mathrm{ac}}$ & 4.41 & $109.99^{\mathrm{A}}$ & 8.17 \\
\hline 5 & $68.77^{\mathrm{a}}$ & 0.88 & 63.31 & 0.61 & $57.70^{\mathrm{aAb}}$ & 4.68 & 66.90 & 5.91 & $76.76^{\mathrm{A}}$ & 2.82 & $74.11^{\mathrm{b}}$ & 1.75 \\
\hline 6 & $41.93^{\mathrm{a}}$ & 2.96 & $40.05^{\mathrm{b}}$ & 0.36 & $31.26^{\mathrm{ab}}$ & 2.18 & 35.46 & 1.48 & $46.22^{\mathrm{c}}$ & 1.92 & 40.69 & 1.81 \\
\hline 7 & 63.80 & 4.72 & 61.93 & 1.68 & $55.93^{\mathrm{Aa}}$ & 4.12 & 61.76 & 3.87 & $78.05^{\mathrm{A}}$ & 0.51 & $77.07^{\mathrm{a}}$ & 0.99 \\
\hline 8 & $44.97^{\mathrm{a}}$ & 2.67 & $45.04^{\mathrm{b}}$ & 0.49 & $33.65 \mathrm{a}^{\mathrm{bc}}$ & 2.53 & 40.09 & 1.79 & $47.63^{\mathrm{c}}$ & 0.68 & 44.09 & 1.39 \\
\hline 9 & $75.19^{\mathrm{A}}$ & 6.78 & 66.83 & 0.41 & $52.77 \mathrm{~A}^{\mathrm{B}}$ & 3.29 & 59.94 & 1.95 & $79.56^{\mathrm{B}}$ & 5.13 & 69.92 & 4.59 \\
\hline 10 & 70.55 & 2.38 & $72.76 \mathrm{~A}$ & 1.32 & $60.16^{\mathrm{A}}$ & 1.17 & 64.98 & 1.74 & 60.96 & 0.76 & 57.20 & 1.30 \\
\hline 11 & $49.25^{\mathrm{a}}$ & 0.83 & $47.77^{\mathrm{Ab}}$ & 0.82 & 54.01 & 3.97 & $59.01^{\mathrm{A}}$ & 5.76 & 59.08 & 1.20 & $62.70^{\mathrm{ab}}$ & 2.88 \\
\hline 12 & 75.64 & 1.15 & $81.88^{\mathrm{Aa}}$ & 0.64 & 67.25 & 5.41 & $62.65^{\mathrm{A}}$ & 8.01 & 61.04 & 3.94 & $55.03^{\mathrm{a}}$ & 4.81 \\
\hline 13 & $39.73 \mathrm{a}^{\mathrm{bA}}$ & 0.57 & $37.80^{\mathrm{c}}$ & 0.85 & $33.97^{\mathrm{a}}$ & 0.67 & $34.11 \mathrm{~b}$ & 1.11 & 34.24 & 1.07 & $31.33^{\mathrm{Ac}}$ & 2.48 \\
\hline 14 & 55.43 & 2.28 & 49.57 & 1.81 & 49.11 & 1.50 & 48.87 & 2.86 & 50.27 & 2.18 & 49.87 & 1.16 \\
\hline 15 & $34.43^{\mathrm{ab}}$ & 0.40 & 32.40 & 1.36 & $28.22^{\mathrm{ac}}$ & 0.83 & $27.98^{\text {bd }}$ & 0.37 & $34.70^{\text {cd }}$ & 1.15 & 32.37 & 2.02 \\
\hline 16 & $115.20^{\mathrm{ab}}$ & 3.57 & 110.76 & 2.06 & 108.31 & 2.85 & $105.02^{\mathrm{a}}$ & 5.59 & $101.13^{b}$ & 3.42 & 104.77 & 5.46 \\
\hline 17 & $63.39^{\mathrm{ab}}$ & 1.72 & 57.14 & 1.49 & $41.27^{\mathrm{a}}$ & 5.51 & 46.13 & 8.07 & 41.40 & 4.52 & $38.80^{\mathrm{b}}$ & 5.03 \\
\hline 18 & 114.47 & 3.25 & 116.44 & 3.57 & 115.19 & 13.91 & 112.90 & 7.05 & 123.98 & 9.88 & 121.89 & 13.32 \\
\hline 19 & $\underset{A}{94.28^{a b c}}$ & 23.99 & $248.22^{\mathrm{d}}$ & 20.60 & $327.05^{\mathrm{a}}$ & 43.81 & $330.37^{b}$ & 30.32 & $1129.39^{c}$ & 31.93 & 1292.09 & 169.16 \\
\hline
\end{tabular}

Explanation: means bearing the same large letter within each line differ significantly at $\mathrm{P}<0.01$; means bearing the same small letter within each line differ significantly at $\mathrm{P}<0.05$.

than those for Tuj and Morkaraman sheep skulls and Indian Kagani goats (Sarma, 2006). Also the breadth of the occipital condyles in the Polish Heat Sheep is smaller than that in the Tuj and Morkaraman sheep skulls. The breadth of the neurocranium and breadth of the occipital bone, in the Polish Heath Sheep skulls are considerably larger than those in sheep and goats mentioned above, which should be linked to the setting of huge horns. 
The values of biometric characteristics of the skulls of regional Northern sheep obtained in this study may be also compared with the tables that show dimensions of other sheep and goat breeds from different continents which have been extensively presented on the occasion of studying the skulls of sheep from Trinidad (Mohamed et al.). The findings of this study can support the search for evolutionary foundations for the population of horned domestic sheep, as well as reflect the evolutionary distinctiveness of this breed and confirm its unique nature, constituting the basis for its protection within the framework of genetic diversity conservation and preservation scheme. The presented morphometric study also complement DNA analyses being currently carried out in order to identify a subspecies.

BARANOWSKI, P. Características craneométricas e índices craneales de de ovejas Heath polacas - datos ampliados. Int. J. Morphol., 35(1):133140, 2017.

RESUMEN: El estudio se realizó en la raza preservada de ovejas Heath, derivadas del Muflón. En este estudio se analizaron las mediciones craneales básicas de 24 cráneos de carneros de diferentes edades: 1 día, 90 días, 210 días, 270 días, 3 y 6 años. Se determinó el peso de cada cráneo, se midieron 43 características craneométricas y se calculó el volumen de la cavidad craneal y los índices viscerocraneales y neurocraneales. Desde el nacimiento hasta la edad de 6 años, la longitud más grande del cráneo, la longitud del cóndilo y la longitud de la hilera del diente de la mejilla aumentó dos veces. A los 210 días de edad, la cubierta ósea para el bulbo ocular y sus órganos creció intensivamente. Al día 270 de edad, el mayor incremento fue la longitud angular del neurocráneo y su amplitud. Los elementos estructurales que caracterizan tanto el ancho como la longitud del viscerocráneo se desarrollaron a la edad de 6 años. Se observó un valor significativo $(\mathrm{P} \leq 0,05)$, decreciente con la edad, del índice cefálico, siendo afectado principalmente por el desarrollo de la parte escamosa del hueso frontal con su parte orbitaria y el margen orbital.

PALABRAS ClAVE: Medidas de Cráneo; Neurocráneo; Viscerocraneo; Ovejas polacas; Razas en peligro de extinción.

\section{REFERENCES}

Baranowski, P.; Binerowska, B. \& Romanczuk, T. Comparing selected biometric traits and horn traits of Polish Heath Sheep rams (Ovis aries), mouflon rams (Ovis orientalis musimon, Schreber 1782) and interspecies hybrids. Folia Univ. Agric. Stetin. Zootech., 250(48):145-56, 2006.

Baranowski, P. \& Furkioti, K. Selected craniometrical features and cranial indices of the Polish Heath sheep rams in the first year of life. Folia Univ. Agric. Stetin. Agric. Aliment. Pisc. Zootech., 257(3):39-50, 2007.

Binerowska, B. \& Baranowski, P. Some body features and biochemical indices of the blood plasma of growing and adult Polish Heath Sheep rams in the seasonal rhythm. Part 1. Selected features of ram horn morphology. Acta Sci. Pol. Zootech., 9(4):15-24, 2010.

Barker, J. S. F. Conservation and management of genetic diversity: a domestic animal perspective. Can. J. For. Res., 31(4):588-95, 2001.

Czaja, M. Studia Nad wrzosówka. Pol. Tow. Zoot., 7-119, 1937.

Driesch A. von den. A guide to the measurement of animal bones from archaeological sites. Harvard University, 1976.

Ekman, S. De Svenska lantrasfåren Gotlands untegångsfår. Gutefåret, 4:1-7, 2006.

Flannery, K. V. The Animal Bones. In: Hole, F.; Flannery, K. V. \& Neeley, J. (Eds.). Prehistory and Human Ecology of the Deh Luran Plain. Memoirs of the Museum of Anthropology 1. Ann Arbor, University of Michigan, 1969.
Kapitanova, D. V.; Lopatin, A. V.; Subbotin, A. E. \& Wall, W. A. Cranial morphometry and taxonomy of argali, Ovis ammon (Artiodactyla, Bovidae), from former Soviet Union and Mongolia. Russ. J. Theriol., 3(2):89-106, 2004.

Kiec, W. The productivity of Polish Wrzosówka sheep in conditions of preservation. Anim. Genet. Resour. Inf., 27:35-42, 2000.

Laprus-Madej, B. Podstawy konsumpcji mie sa w neolicie na terenie ziem polskich. Stud. Mater. Archeol., 32:89-120, 2000.

Lasota-Moskalewska, A.; Kobryn, H. \& S'wiez yn'ski, K. Two forms of domestic goats in Europe and Asia from Neolithic Age to the Middle Ages. Acta Theriol., 36:329-48, 1991.

Lincoln, G. A. Reproductive seasonality and maturation throughout the complete life-cycle in the mouflon ram (Ovis musimon). Anim. Reprod Sci., 53(14):87-105, 1998.

Mallet, C. \& Guadelli, J. L. Eléments de distinction des portions pétreuses de temporal d'Ovis aries et de Capra hircus; applications des caractéres à la distinction de quelques autres Caprinae (Capra ibex, Rupicapra rupicapra). Paleo, 24:173-91, 2013.

Mohamed, R.; Driscoll, M. \& Mootoo, N. Clinical anatomy of the skull of the Barbados Black Belly sheep in Trinidad. Int. J. Curr. Res. Med. Sci., 2(8):819, 2016.

Niznikowski, R.; Marciniec, M. \& Wozniakowska, A. Comparison of the level of reproduction traits and body weight at birth of Polish Heath kept indoors and in free ranching environment. Ann. Warsaw Agric. Univ. S. G. G. W. Anim. Sci., 39:29-33, 2002.

Özcan, S.; Aksoy, G.; Kürtül, I.; Aslan, K. \& Özüdogru, Z. A comparative morphometric study on the skull of the tuj and morkaraman sheep. Kafkas Univ. Vet. Fak. Derg., 16(1):111-4, 2010.

Santiago-Moreno, J.; Gómez-Brunet, A.; Toledano-Díaz, A.; González-Bulnes, A.; Picazo, R. A. \& López-Sebastián, A. Influence of age on the relationship between annual changes in horn growth rate and prolactin secretion in the European mouflon (Ovis gmelini musimon). Anim. Reprod. Sci., 85(3-4):251$61,2005$.

Sarma, K. Morphological and craniometrical studies on the skull of Kagani Goat (Capra hircus) of Jammu Region. Int. J. Morphol., 24(3):449-55, 2006.

Parés-Casanova, P. M.; Kamal, S. \& Jordana, J. On biometrical aspects of the cephalic anatomy of Xisqueta Sheep (Catalunya, Spain). Int. J. Morphol., 28(2):347-51, 2010

Parés-Casanova, P. M. Osteometric study of the Rasquera goat. J. Appl. Anim. Res., 42(2):177-85, 2014.

Ryder, M. L. A survey of European primitive breeds of sheep. Ann. Génét. Sél. Anim., 13(4):381-418, 1981.

Scherf, B. D. World Watch List for Domestic Animal Diversity. 3rd ed. Rome, Food and Agriculture Organization of the United Nations, 2000.

Schramm, Z. Róznice morfologiczne niektórych kosci kozy i owcy. Roczniki Wyzszej Szko?y Rolniczej w Poznaniu, 36:107-33, 1967.

Tapio, I.; Tapio, M.; Grislis, Z.; Holm, L. E.; Jeppsson, S.; Kantanen, J.; Miceikiene, I.; Olsaker, I.; Viinalass, H. \& Eythorsdottir, E. Unfolding of population structure in Baltic sheep breeds using microsatellite analysis. Heredity (Edinb.), 94(4):448-56, 2005

Corresponding author:

Prof. Piotr Baranowski, PhD, DSc

Department of Animal Anatomy

Faculty of Biotechnology and Animal Husbandry

Western Pomeranian University of Technology in Szczecin

14 Doktora Judyma St.

71-466 Szczecin

POLAND

Email: Piotr.Baranowski@zut.edu.pl

Received: 15-11-2016

Accepted: 22-12-2016 